\title{
Enhancement of endogenous neurogenesis in ephrin-B3 deficient mice after transient focal cerebral ischemia
}

\author{
Thorsten R. Doeppner • Eva Bretschneider • Maria Doehring • \\ Inmaculada Segura $\cdot$ Aycan Sentürk • Amparo Acker-Palmer • \\ Mohammad R. Hasan · Ayman ElAli · Dirk M. Hermann • Mathias Bähr
}

Received: 22 March 2011/Revised: 1 July 2011/Accepted: 2 July 2011/Published online: 21 July 2011

(c) Springer-Verlag 2011

\begin{abstract}
Cerebral ischemia stimulates endogenous neurogenesis. However, the functional relevance of this phenomenon remains unclear because of poor survival and low neuronal differentiation rates of newborn cells. Therefore, further studies on mechanisms regulating neurogenesis under ischemic conditions are required, among which ephrin-ligands and ephrin-receptors (Eph) are an interesting target. Although Eph/ephrin proteins like ephrin-B3 are known to negatively regulate neurogenesis under physiological conditions, their role in cerebral ischemia is largely unknown. We therefore studied neurogenesis, brain injury and functional outcome in ephrin-B3 ${ }^{-1-}$ (knockout) and ephrin-B $^{+/+}$(wild-type) mice submitted to cerebral ischemia. Induction of stroke resulted in enhanced cell proliferation and neuronal differentiation around the
\end{abstract}

T. R. Doeppner $(\bowtie) \cdot$ M. R. Hasan · A. ElAli · D. M. Hermann Department of Neurology, University of Duisburg-Essen Medical School, Hufelandstr. 55, 45122 Essen, Germany e-mail: thorsten.doeppner@uk-essen.de

T. R. Doeppner - E. Bretschneider · M. Doehring · M. Bähr Department of Neurology, University of Goettingen Medical School, 37075 Goettingen, Germany

I. Segura · A. Sentürk · A. Acker-Palmer

Frankfurt Institute for Molecular Life Sciences (FMLS) and Institute of Cell Biology and Neurosciences,

Goethe University Frankfurt, 60438 Frankfurt am Main,

Germany

Present Address:

I. Segura

Vesalius Research Center (VRC) VIB, 3000 Leuven, Belgium

M. Bähr

DFG Research Center for the Molecular Physiology

of the Brain (CMPB), Göttingen, Germany lesion site of ephrin-B $3^{-/-}$compared to ephrin- $3^{+/+}$mice. However, prominent post-ischemic neurogenesis in ephrin$\mathrm{B}^{-1-}$ mice was accompanied by significantly increased ischemic injury and motor coordination deficits that persisted up to 4 weeks. Ischemic injury in ephrin-B $3^{-1-}$ mice was associated with a caspase-3-dependent activation of the signal transducer and activator of transcription 1 (STAT1). Whereas inhibition of caspase-3 had no effect on brain injury in ephrin- $\mathrm{B} 3^{+/+}$animals, infarct size in ephrin- $\mathrm{B} 3^{-/-}$ mice was strongly reduced, suggesting that aggravated brain injury in these animals might involve a caspase-3-dependent activation of STAT1. In conclusion, post-ischemic neurogenesis in ephrin-B ${ }^{-/-}$mice is strongly enhanced, but fails to contribute to functional recovery because of caspase-3mediated aggravation of ischemic injury in these animals. Our results suggest that ephrin-B3 might be an interesting target for overcoming some of the limitations of further cellbased therapies in stroke.

Keywords Caspase-3 - Cerebral ischemia .

Endogenous neurogenesis · Ephrin-B3

Neural precursor cells $\cdot$ STAT1

\section{Introduction}

Endogenous neurogenesis persists within distinct areas of the adult mammalian brain such as the subventricular zone (SVZ) [19, 36, 37]. Within this germinal niche, astrocytelike neural stem cells give rise via rapidly dividing cells to neuroblasts, which migrate along the rostral migratory stream towards the olfactory bulb, where they differentiate into mature neurons $[1,13,14]$.

Various physiological and pathological stimuli enhance neurogenesis, among which cerebral ischemia is known to 
stimulate both proliferation and differentiation of immature neural precursor cells (NPCs) [2, 23, 27, 45]. Although increased neurogenesis under ischemic conditions could contribute to regeneration and restoration, the functional relevance of this phenomenon remains unclear because of poor survival and low neuronal differentiation rates of newborn cells [9, 47]. In order to develop successful neuroregenerative concepts, further knowledge of mechanisms regulating adult neurogenesis under ischemic conditions is urgently needed.

In this context, membrane-bound ephrin proteins interacting via their corresponding ephrin receptors (Ephreceptor) in a bidirectional way [15] have gained increasing attention as signaling molecules associated with neurogenesis. These proteins have diverse roles during prenatal development of the brain with special emphasis on axonal guidance, cell-cell-adhesion and synaptic plasticity [29, 43]. In the adult mammalian brain, ephrin-B2 and ephrin-B3 blockade successfully increased both proliferation and migration of SVZ-derived NPCs under physiological conditions [8, 32]. So far, only one study has analyzed the role of ephrins in the ischemic brain, reporting an increase in proliferation and neuronal differentiation of SVZ-derived NPCs after competitive inhibition of Eph-B2 [44]. In the current study, we show that endogenous neurogenesis is increased after transient focal cerebral ischemia in ephrin-B3 knockout mice without contributing to functional neurological recovery. On the contrary, brain injury in these animals is highly enhanced, involving a caspase-3-associated activation of the signal transducer and activator of transcription 1 (STAT1). We propose that aggravated ischemic brain injury in ephrin-B3 knockout animals is associated with a caspase3-dependent phosphorylation of STAT1.

\section{Materials and methods}

\section{Experimental groups}

Experimental procedures were performed according to the European Institutes of Health guidelines for the care and use of laboratory animals and approved by local authorities. Animals were housed under circadian conditions and had free access to food and water. The ephrin-B3 null mice used in the study were kindly provided by Nicholas W. Gale (Regeneron Pharmaceuticals Inc., Tarrytown, NY) and generated as described previously [25].

For all experiments, adult male ephrin-B3 knockout (ephrin-B3 ${ }^{-/}$) and wild-type mice (ephrin-B3 ${ }^{+/+}$) with an age of 11-14 weeks weighing $25-28 \mathrm{~g}$ were used. The total number of animals used was 204. Mice were killed on day 4, 14 and 28 after induction of stroke. Animals used for infarct analysis on day 28 (8 animals each) were also used for behavioral tests. Remaining experimental groups (4- and 14-day survival) consisted of seven animals each. For Western blot, caspase-3 analysis and vessel staining four animals per condition were used. Survival rate was $100 \%$ for all experimental groups except for ephrin-B3 ${ }^{-/-}$ mice that survived for 28 days, $88.9 \%$ for animals used for TTC staining or immunohistochemistry and $80 \%$ for animals used for pump implantation experiments. Postischemic cell proliferation was analyzed using intraperitoneal (i.p.) injection of 5-bromo-2-deoxyuridine (BrdU; Sigma, Germany) on days 0-3 (4-day survival), days 8-13 (14-day survival) or days 8-18 (28-day survival) with a daily dose of $50 \mathrm{mg} / \mathrm{kg}$ bodyweight.

Preparation and cultivation of SVZ-derived neural precursor cells

Preparation and subsequent cultivation of NPCs was done according to a modified protocol from Rietze and Reynolds [33]. NPCs were isolated from the SVZ of 6-8-week-old ephrin-B3 ${ }^{-1-}$ and wild-type mice. The SVZ was micro-dissected under stereomicroscopic control (Zeiss, Germany) and minced into small pieces, and then mechanically triturated and dissociated to single cell suspension. Cells were cultured in serum-free basic medium DMEM-F12 (PAA, Austria) supplemented with epidermal growth factor (EGF, $2 \mu \mathrm{g} / \mathrm{ml}$ ), basic fibroblast growth factor (bFGF, $2 \mu \mathrm{g} / \mathrm{ml}$ ) and penicillin-streptomycin (Invitrogen, Germany). Cells were incubated with $5 \% \mathrm{CO}_{2}$ at $37^{\circ} \mathrm{C}$. The growth factors were added every $2-3$ days, and the cells were passaged by accutase digestion and then re-suspended in pre-warmed conditioned media. Neurosphere passage was done every 7-10 days, and the cells used for experiments were harvested after passage 2-3.

Quantitative neurosphere analysis and proliferation assay

For analysis of neurosphere numbers and neurosphere proliferation, 10,000 NPCs were plated in six-well plates and cultured for 7 days followed by a quantitative analysis of the number of primary neurospheres. The neurospheres were collected with a pipette and transferred to 24-well plates with coverslips coated with $1 \mathrm{mg} / \mathrm{ml}$ poly-D-lysine (Sigma, Germany) and $5 \mu \mathrm{g} / \mathrm{ml}$ laminin (Invitrogen, Germany) for immunostaining. The neurospheres were fixed with $4 \%$ paraformaldehyde (PFA) for $1 \mathrm{~h}$ at $4^{\circ} \mathrm{C}$, washed in PBS, blocked for $1 \mathrm{~h}$ in blocking solution $[0.2 \%$ TritonX-100 and $3 \%$ bovine serum albumin (BSA) in PBS] and incubated overnight with rabbit anti-phosho-histone-H3 antibody (1:50; Cell Signaling, USA) at $4^{\circ} \mathrm{C}$. The neurospheres were then washed and stained with an anti-rabbit Cy3-conjugated secondary 
antibody (1:200; Jackson ImmunoResearch, USA). For detection of the cell nuclei sections were stained with DAPI (1:20,000; Roth, Germany). The images were acquired using a confocal microscope (Leica TCS SP2) equipped with a $20 \times$ objective, and quantitative measurements were performed using MetaMorph software (Molecular Devices, UK).

\section{Neurosphere differentiation assay}

For assessment of more subtle differences in cell differentiation, primary neurospheres that had been cultured for 7 days (see above) and neurospheres from passage 3 were gently triturated and plated on 24 -well plates (40 cells/ $\mu \mathrm{l})$ containing coverslips coated with $1 \mathrm{mg} / \mathrm{ml}$ poly-D-lysine (Sigma, Germany) according to modified protocols [5, 7]. Plating medium consisted of DMEM/F12 medium supplemented with 2\% B27 (Invitrogen, Germany), 1\% fetal bovine serum (FBS) and penicillin-streptomycin to allow differentiation of cells. For Western blot analysis, cells were lysed $(50 \mathrm{mM}$ Tris at $\mathrm{pH} 8.0,150 \mathrm{mM} \mathrm{NaCl}$ and Triton $1 \%$ ) on day 7 after plating. Lysates were centrifuged and supernatants were used for SDS-PAGE. Equal amounts of protein $(75 \mu \mathrm{g})$ were diluted in $6 \times$ sample buffer, boiled and loaded onto $10 \%$ polyacrylamide gels. Proteins were transferred onto PVDF membranes, which then were immersed in blocking solution $[5 \%$ milk in TBS-T $(0.1 \%$ Tween $20+\mathrm{TBS}) ; 1 \mathrm{~h}$ at RT] and incubated with primary antibodies (solved in TBS-T with $1 \%$ milk; $18 \mathrm{~h}$ at $4^{\circ} \mathrm{C}$ ). The following primary antibodies were used: rabbit polyclonal anti-nestin $(1: 2,000)$, rabbit polyclonal anti-glial fibrillary acidic protein (GFAP; $1: 10,000)$, rabbit polyclonal anti-2 $2^{\prime}, 3^{\prime}$-cyclic nucleotide 3'-phosphodiesterase (CNPase; $1 \mu \mathrm{g} / \mathrm{ml}$ ) and anti-beta tubulin III $(1 \mu \mathrm{g} / \mathrm{ml}$; all obtained from Abcam, UK). Subsequently, membranes were incubated with a peroxidase-coupled, goat anti-rabbit secondary antibody (1:2,000; Abcam, UK), washed several times, immersed in ECL solution and exposed to ECL-Hyperfilm (Amersham, Germany).

\section{Oxygen-glucose-deprivation (OGD) test}

NPCs from both ephrin-B $3^{+/+}$and ephrin-B $3^{-/-}$mice were passaged, and 1,00,000 cells were used for each condition. Before beginning OGD, cell culture medium was substituted by a crystalloid solution that does not contain any glucose ("Thomajodin" plus $1 \mathrm{mM}$ mannitol; DeltaPharm, Germany), and the cells were incubated in a hypoxic chamber $\left(1 \% \mathrm{O}_{2}, 5 \% \mathrm{CO}_{2}\right.$ and $\left.94 \% \mathrm{~N}_{2}\right)$ for $45 \mathrm{~min}$ and re-incubated in normal glucose-containing cell culture medium for $24 \mathrm{~h}$. The number of dead cells was counted using a LIVE/DEAD-Viability/Cytotoxicity-Assay kit (Lonza, Switzerland). SVZ-derived NPCs from both ephrin-B3 ${ }^{+/+}$and ephrin-B $3^{-/-}$mice that were incubated for $24 \mathrm{~h}$ under standard cell culture conditions served as negative controls.

Induction of focal cerebral ischemia

Animals were anesthetized $\left(0.8-1.5 \%\right.$ isofluran, $30 \% \mathrm{O}_{2}$, remainder $\mathrm{N}_{2} \mathrm{O}$ ), and rectal temperature was maintained at 36.5-37. $0^{\circ} \mathrm{C}$ employing a feedback-controlled heating system. For assessment of blood flow changes, laser Doppler flow (LDF) was recorded during all experiments using a flexible fiberoptic probe (Perimed, Sweden), which was attached to the skull overlying the core region of the middle cerebral artery (MCA) territory ( $2 \mathrm{~mm}$ posterior, $6 \mathrm{~mm}$ lateral from bregma). Cerebral ischemia was induced by transient occlusion of the MCA using the intraluminal filament technique as described previously [12]. Briefly, following a midline neck incision, the left common and external carotid artery were isolated and ligated. After placing a microvascular clip (Aesculap, Germany) on the internal carotid artery, a 7-0 silicon coated nylon monofilament (180 $\mu \mathrm{m}$ tip diameter; Doccol, USA) was introduced through an incision into the distal part of the common carotid artery and, after removing the clip, advanced $9 \mathrm{~mm}$ distal from the carotid bifurcation for MCA occlusion. To achieve transient ischemia, the monofilament was removed after $30 \mathrm{~min}$ (or $20 \mathrm{~min}$ in some ephrin-B3 ${ }^{-/-}$mice to achieve similar infarct sizes). LDF recordings continued for $15 \mathrm{~min}$ after thread removal to monitor appropriate reperfusion.

\section{Intraventricular pump implantation}

Ephrin-B3-Fc ligands (R\&D Systems, Germany; $160 \mu \mathrm{g} / \mathrm{ml}$ solved in PBS) were pre-clustered for $2 \mathrm{~h}$ at room temperature (RT) (anti-human-Fc ratio 5:1; Jackson Research Laboratories, UK) and applied for intraventricular infusion using a modified protocol from Ricard et al. [32]. Ephrin$\mathrm{B}^{-1-}$ mice were anesthetized (see above) 1 day before induction of stroke, and cannulae (Brain Infusion Kit; Alzet, USA), which were linked to mini osmotic pumps (volume $200 \mu \mathrm{l}$, rate $0.25 \mu \mathrm{l} / \mathrm{h}$; model Alzet 2004) filled with Ephrin-B3-Fc ligands, were implanted into the left lateral ventricle through a burr hole [31]. Clustered Fc fragments were used as controls. Infusion was performed over a 28 -day period, and the animals were killed on day 28 poststroke for further analysis.

Immunohistochemistry

Animals were i.p. injected with chloralhydrate $(420 \mathrm{mg} / \mathrm{kg}$ body weight) and transcardiacally perfused with $4 \%$ PFA at 
day 4,14 or 28 after cerebral ischemia. Brains were removed, post-fixed in PFA and embedded in paraffin, and coronal sections $(2 \mu \mathrm{m})$ were prepared. Sections were deparaffinized, boiled in $0.2 \%$ citrate buffer and incubated with blocking solution $(0.3 \%$ Triton X-100; $10 \%$ normal goat serum in PBS; $1 \mathrm{~h}, \mathrm{RT})$. For analysis of $\mathrm{BrdU}^{+}$or $\mathrm{Ki}-67^{+}$cells, sections were exposed to blocking solution and subsequently stained with a rat monoclonal anti-BrdU antibody $\left(1: 50 ; 18 \mathrm{~h}, 4^{\circ} \mathrm{C}\right.$; Serotec, Germany), or a rabbit monoclonal anti-Ki-67 antibody $\left(1: 100 ; 18 \mathrm{~h}, 4^{\circ} \mathrm{C}\right.$; Abcam, UK) and a goat anti-rat Alexa 594 (1:500, $1 \mathrm{~h}$; Molecular Probes, Germany), or a donkey anti-rabbit Alexa Fluor 568 (1:400, $1 \mathrm{~h}$; Molecular Probes, Germany) secondary antibody. For differentiation analysis of $\mathrm{BrdU}^{+}$cells, sections were incubated with a mouse monoclonal anti-BrdU antibody (1:500; Roche, Germany), a goat polyclonal antidoublecortin antibody (1:50; Santa Cruz Biotechnology, Germany), a rat polyclonal anti-GFAP antibody (1:500; Zymed, Germany) or a rat biotin-conjugated anti-IB 4 antibody (1:100; Vector, UK) for $18 \mathrm{~h}$ at $4^{\circ} \mathrm{C}$. For double staining against BrdU and NeuN or CNPase, a rat monoclonal anti-BrdU antibody (see above) and a mouse monoclonal anti-NeuN antibody $\left(1: 200,18 \mathrm{~h}, 4^{\circ} \mathrm{C}\right.$; Chemicon, UK) or a mouse monoclonal anti-CNPase antibody (1:400; Chemicon, Germany) were used. After washing, sections were incubated for $1 \mathrm{~h}$ at RT with the following secondary antibodies: goat anti-mouse Cy-3 (1:400; Dianova, Hamburg, Germany) or goat anti-rat Alexa 594 (1:400; Dianova, Hamburg, Germany) for BrdU staining, goat anti-rat Alexa 488 (1:250; Molecular Probes) or donkey anti-goat Alexa 488 (1:250; Molecular Probes) for GFAP or doublecortin (Dcx) staining, goat anti-mouse Cy-3 (1:100; Jackson Immuno-Research, UK) for CNPase staining and goat anti-mouse Alexa 488 (Molecular Probes, Germany) for NeuN (1:400) staining.

TUNEL staining was performed incubating sections with proteinase $\mathrm{K}\left(7 \mathrm{~min}, 37^{\circ} \mathrm{C}\right)$, followed by exposure to the TdT enzyme reaction according to the manufacturer's manual (Roche, Germany). After several washing steps and exposure to TUNEL blocking solution (20 min, RT), sections were stained with a streptavidin-Alexa594conjugated secondary antibody $(2 \mathrm{~h}, \mathrm{RT}$; Molecular Probes).

Quantitative analysis of post-stroke cell injury, cell proliferation and differentiation

Infarct volume analysis was performed on days 4, 14 and 28. Brains were removed and cut into four $2-\mathrm{mm}$ slices. Slices were stained with 2,3,5-triphenyltetrazolium chloride (TTC, 2\%), and computer-based analysis of infarct volumes was done using the software Image $\mathbf{J}$ as previously described [12]. Assessment of post-ischemic edema formation was performed as the increase of ipsilateral hemispheric volume in comparison to the contralateral hemisphere as described by Wacker et al. [41].

Quantitative analyses for immunohistochemical stainings were performed, defining regions of interest (ROIs) within the SVZ and the basal ganglia (BG). Stereotactic coordinates for quantitative analysis in the SVZ were $0.14 \mathrm{~mm}$ anterior, $2-3 \mathrm{~mm}$ ventral and $1-1.25 \mathrm{~mm}$ lateral from bregma. Cell count analysis within the BG was done at $0.14 \mathrm{~mm}$ anterior, $2.5-3.25 \mathrm{~mm}$ ventral and $1.5-2.25 \mathrm{~mm}$ lateral from bregma. Three sections per animal and ROI were used. Cell death (TUNEL) and neuronal density (NeuN) were assessed within ischemic BG. The number of proliferating cells (BrdU and Ki-67) was determined within the BG and the SVZ. Analysis of cell differentiation was performed using the different markers stated above with subsequent re-calculation as percentages of $\mathrm{BrdU}^{+}$cells. For assessment of general post-ischemic neuronal differentiation, total numbers of $\mathrm{Dcx}^{+}$cells and $\mathrm{NeuN}^{+} / \mathrm{BrdU}^{+}$cells within the ischemic BG are given. Data on cell proliferation and differentiation reflect total numbers of counted cells within the SVZ and the BG.

Visualization of anastomotic lines between the anterior cerebral artery (ACA) and the middle cerebral artery territory

In order to exclude increased brain injury of ephrin-B3 ${ }^{-/-}$ mice due to differences in macroscopic vessel anatomy, vessel visualization was done following a modified protocol as described previously by us [42]. Non-ischemic ephrin-B3 ${ }^{+/+}$and ephrin-B3 ${ }^{-/-}$mice were anaesthetized with $1 \%$ isoflurane and injected with a lethal dose of papaverine hydrochloride $(50 \mathrm{mg} / \mathrm{kg} \mathrm{BW})$ intracardially to ensure maximal vasodilatation and vascular filling followed by infusion of $2 \mathrm{ml}$ saline. The thoracic aorta was clipped and the ascending aorta was cannulated. Carbon black solution was prepared with two commercially available inks, i.e., $1.8 \mathrm{ml}$ of Scribtol (Pelikan, Germany) and $0.2 \mathrm{ml}$ of Stempelfarbe (Herlitz, Germany). Five minutes after injection of papavarine, $2 \mathrm{ml}$ of saline was injected into the left ventricle, and immediately afterwards $2 \mathrm{ml}$ of carbon black solution was injected with slight pressure over $40-50 \mathrm{~s}$. After $10 \mathrm{~min}$, animals were decapitated and brains were removed. Photographs of the dorsal and ventral brain surfaces were taken immediately after removal of the brain. Anastomotic lines between ACA and MCA territories were localized by tracing peripheral branches to the points at which vessels were connected. The distance from the midline to the line of anastomosis of the left hemisphere was measured in coronal planes at bregma and at $+1 \mathrm{~mm}$ from bregma. 
These levels corresponded to areas where lesion sites were always induced.

Analysis of post-stroke functional deficits

Functional deficits in motor coordination were assessed using both the rota rod and the tightrope test. One day before induction of stroke, all animals were trained before the beginning of the actual tests on days 7, 14, 21 and 28 post-stroke. The rota rod test was performed using an accelerating treadmill for mice (TSE Systems, Germany; $3 \mathrm{~cm}$ diameter). Mice were placed on the rotating drum with an accelerating speed of 4-40 rpm. Maximum speed was achieved after $260 \mathrm{~s}$, and maximum testing time was $300 \mathrm{~s}$. The time until animals dropped was registered and statistically analyzed. Using the tightrope test, animals were placed on a $60-\mathrm{cm}$-long tightrope grasping the string with their forepaws according to a modified protocol from Gerlai et al. [17]. All animals were tested twice per time point. Maximum test time was $60 \mathrm{~s}$, and results were scored from 0 (minimum) to 20 (maximum) according to a validated score (Table 1) depending on the time animals spent on the rope and whether or not they reached the platform.

Table 1 Assessment of tight rope test performance

\begin{tabular}{|c|c|c|}
\hline Score & Time (s) & Platform arrival \\
\hline 20 & $1-6$ & + \\
\hline 19 & $7-12$ & + \\
\hline 18 & $13-18$ & + \\
\hline 17 & $19-24$ & + \\
\hline 16 & $25-30$ & + \\
\hline 15 & $31-36$ & + \\
\hline 14 & $37-42$ & + \\
\hline 13 & $43-48$ & + \\
\hline 12 & $49-54$ & + \\
\hline 11 & $55-60$ & + \\
\hline 10 & $55-60$ & - \\
\hline 9 & $49-54$ & - \\
\hline 8 & $43-48$ & - \\
\hline 7 & $37-42$ & - \\
\hline 6 & $31-36$ & - \\
\hline 5 & $25-30$ & - \\
\hline 4 & $19-24$ & - \\
\hline 3 & $13-18$ & - \\
\hline 2 & $7-12$ & - \\
\hline 1 & $1-6$ & - \\
\hline 0 & 0 & - \\
\hline
\end{tabular}

Tightrope test results were assessed according to both time on the rope (in seconds) and platform arrival ("+" for arrival and "-" for non-arrival). The scores ranged from 0 (minimum) to 20 (maximum)
Caspase- 3 assays

Caspase-3 activity was determined using the fluorophore substrate Ac-DEVD-AMC (Biomol, Germany) in brain homogenates of ischemic hemispheres at $1,2,3$ and $4 \mathrm{~h}$ after stroke. Whereas control animals received i.v. injections of $100 \mu \mathrm{l}$ of $0.2 \%$ dimethyl sulfoxide (DMSO), others received $100 \mu \mathrm{l}$ of the caspase-3 inhibitor z-DEVD.fmk (Biomol, Germany; $500 \mathrm{ng}$, solved in $0.2 \%$ DMSO) at the beginning of the reperfusion. Left hemispheres were complemented with lysis buffer containing $25 \mathrm{mmol} / \mathrm{l}$ HEPES, pH 7.5, 1 mM EDTA, $10 \mathrm{mM}$ 1,4-dithiothreitol (Roche, Germany), 0.1\% 3-[(3-cholamidopropyl)dimethylammonio]-1-propanesulfonate (CHAPS; Sigma-Aldrich, Germany), $10 \%$ sucrose, $0.1 \%$ Triton X-100 with $10 \mu \mathrm{g} / \mathrm{ml}$ of pepstatin A, aprotinin and leupeptin plus $1 \mathrm{mM}$ phenylmethylsulfonyl fluoride (PMSF; all Sigma-Aldrich, Germany). Samples were homogenized and centrifuged, and supernatants were used for measurements applying $90 \mu \mathrm{l}$ of samples and $10 \mu \mathrm{l}$ of substrate $(50 \mu \mathrm{M})$. Fluorescence $(355-460 \mathrm{~nm})$ was detected at 2-min intervals for $20 \mathrm{~min}$ with a linear increase between 4-16 min. Caspase3 activity was re-calculated from the slope (fluorescence units per time) and is given as picomoles of substrate cleaved per milligram of protein per minute based on a standard curve for 7-amino-4-methylcoumarin (AMC; Biomol, Germany). Protein concentration in the supernatant was determined using the Bradford assay.

For analysis of caspase-3-mediated effects on postischemic injury, animals received $100 \mu \mathrm{l}$ of z-DEVD.fmk (500 ng, solved in $0.2 \%$ DMSO) or $100 \mu \mathrm{l}$ of $0.2 \%$ DMSO via femoral vein injections at the beginning of the reperfusion. Moreover, animals received additional z-DEVD.fmk or DMSO application via tail vein injection on days 1-3 post-stroke. Thereafter, animals were killed on day 4 and infarct volumes were analyzed.

\section{Detection of phosphorylated STAT1 and STAT3}

Phosphorylated STAT1 and STAT3 were measured in brain lysates of ischemic hemispheres at $24 \mathrm{~h}$ after stroke using Western blot analysis. Generation of brain lysates and Western blotting procedure were performed as described above. Animals either received z-DEVD.fmk or $0.2 \%$ DMSO (see above) at the beginning of the reperfusion. The following primary antibodies were used: rabbit anti-phospho-STAT1 $(1: 2,000)$ and rabbit anti-phosphoSTAT3 (1:2,500; both obtained from Millipore, Germany). Thereafter, membranes were incubated with a peroxidasecoupled, goat anti-rabbit secondary antibody (1:2,000; Abcam, UK), washed several times, immersed in ECL solution and exposed to ECL-Hyperfilm (Amersham, Germany). 

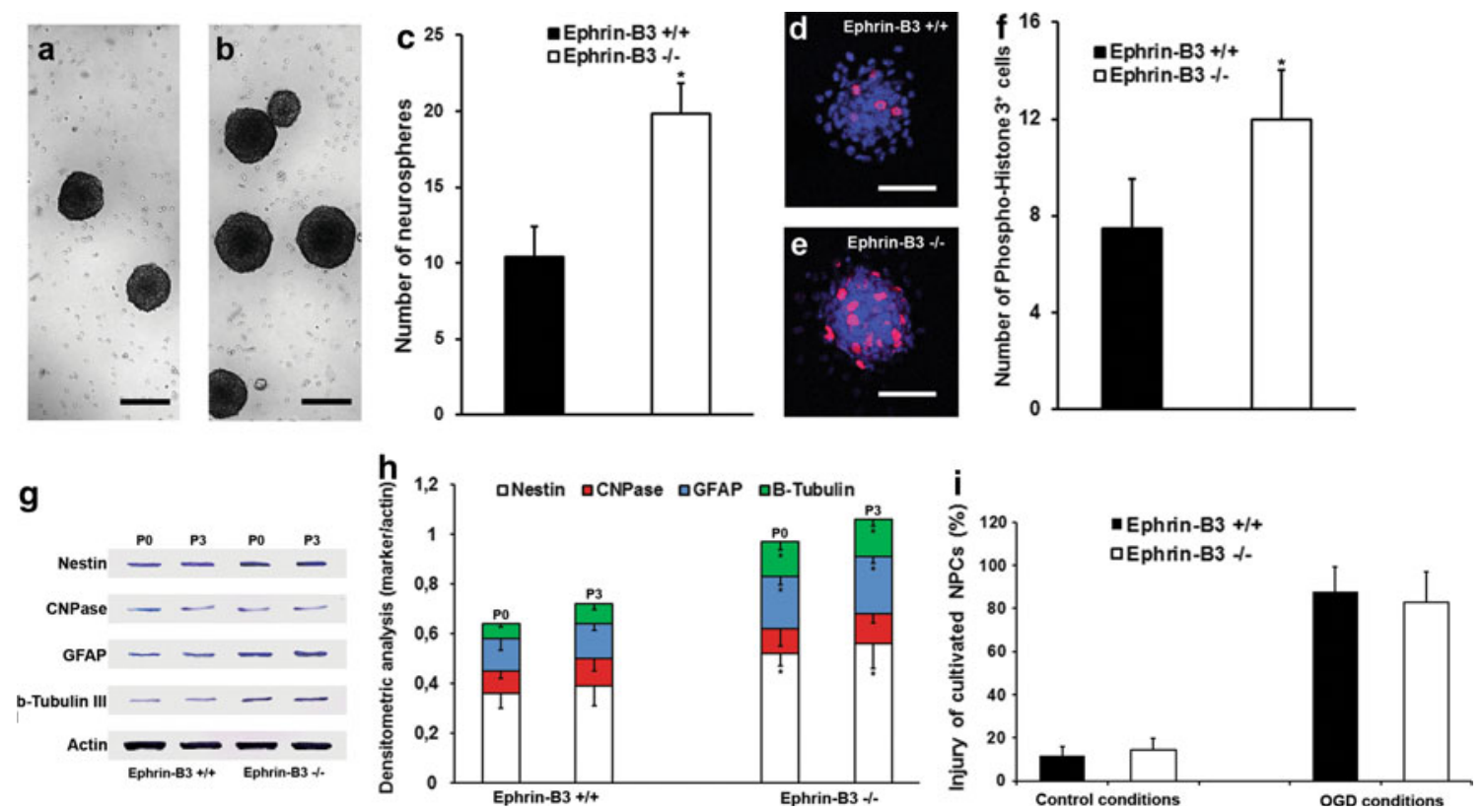

Fig. 1 In vitro characterization of ephrin-B3 ${ }^{-1-}$-derived NPCs. Neurosphere-forming neural precursor cells (NPCs) were derived from subventricular zones (SVZ) of ephrin-B3 ${ }^{+/+}$(a) and ephrin$\mathrm{B} 3^{-I-}$ (b) mice. Primary neurospheres were counted 7 days after cell culture (c). Cell proliferation rates were assessed by staining of neurospheres with anti-phospho-histone $\mathrm{H} 3$ (d-f). Cell differentiation was analyzed using Western blotting (g) against nestin, GFAP, CNPase and beta-tubulin III in primary neurospheres (P0) and

\section{Statistics}

All data are given as mean + standard deviation. For comparison between two groups, the two-sided Student's $t$ test was used. For analysis of score data from the tightrope test, however, the non-parametric Wilcoxon-Mann Whitney test was used. A $p$ value of $<0.05$ was considered to be statistically significant.

\section{Results}

In vitro characterization of SVZ-derived NPCs from ephrin-B $3^{-/-}$mice

NPCs from both mouse strains were first characterized in vitro regarding neurosphere formation, cell proliferation and differentiation as well as behavior after oxygen-glucose deprivation (OGD). Ephrin-B3 ${ }^{-1-}$-derived NPCs showed significantly enhanced primary neurosphere formation and cell proliferation rates compared to controls (Fig. 1a-f). Analysis of cell differentiation in serum containing cell culture medium revealed an increased expression of the neural stem cell/neural progenitor cell marker nestin, the astroglial marker GFAP and the neurospheres from passage 3 (P3). Data (h) are presented as relative protein expression referred to actin expression. i NPCs were exposed to $45 \mathrm{~min}$ of oxygen-glucose deprivation (OGD) and re-cultivated for $24 \mathrm{~h}$ at standard cell culture conditions followed by subsequent analysis of cell injury. Controls were incubated under standard cell culture conditions only without OGD. Scale bars $100 \mu \mathrm{m}$. *Significantly different from ephrin-B $3^{+/+}$mice, $p<0.05$

neuronal marker beta-tubulin III in NPCs derived from ephrin-B3 $^{-/-}$mice (Fig. 1g, h). Importantly, protein abundance between primary NPCs (P0) and NPCs from cell culture passage 3 (P3) did not differ within each mouse strain.

To exclude a higher sensitivity of ephrin-B $3^{-1-}$-derived NPCs to hypoxic-hypoglycemic injury, which is relevant for the functional meaning of post-stroke neurogenesis in vivo, NPCs were exposed to a 45-min OGD and subsequently re-cultivated at standard cell culture conditions (Fig. 1i). OGD induced prominent cell injury in NPCs derived from both mouse strains after $24 \mathrm{~h}$ of re-cultivation under standard cell culture conditions. However, we observed no significant difference between cell injury of NPCs that were derived from either ephrin-B3 $3^{-1-}$ or ephrin-B $3^{+/+}$mice.

Analysis of cell proliferation and differentiation after cerebral ischemia

We analyzed post-ischemic cell proliferation in ephrin$\mathrm{B}^{+/+}$and ephrin-B3 ${ }^{-/-}$mice using $\mathrm{Ki}-67$ staining and BrdU staining for up to 4 weeks post-stroke followed by a differentiation analysis of $\mathrm{BrdU}^{+}$cells. Staining against $\mathrm{Ki}-67$, a marker for current cell proliferation, revealed a 

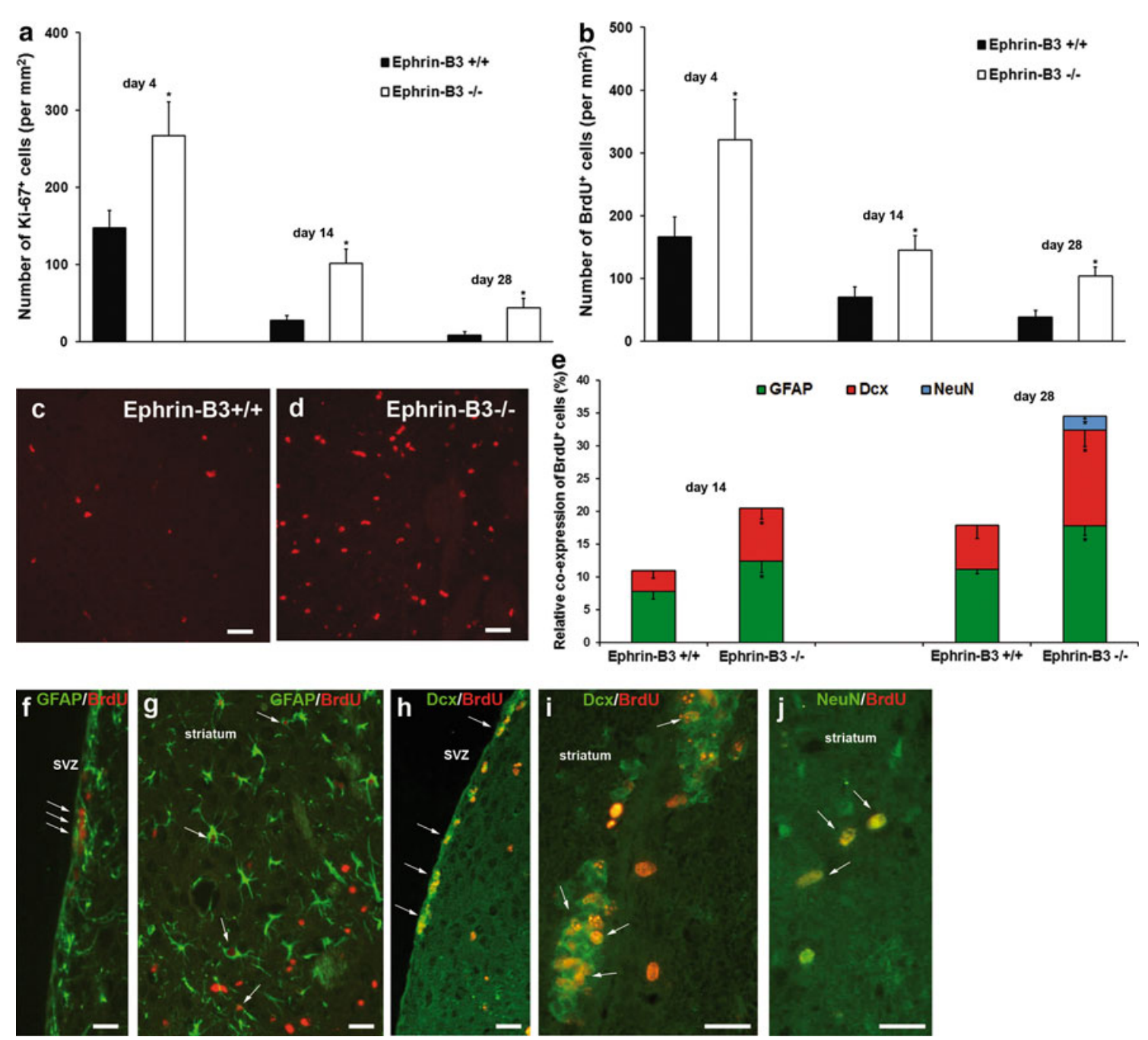

Fig. 2 Analysis of post-ischemic cell proliferation and differentiation. Cell proliferation in ephrin-B $3^{+/+}$and ephrin-B $3^{-/-}$mice was analyzed using $\mathrm{Ki}-67$ (a) and $\mathrm{BrdU}$ (b) staining. $\mathrm{BrdU}^{+}$cells were scattered within the ischemic striatum as exemplarily depicted on day 28 for ephrin-B3 ${ }^{+/+}$(c) and ephrin-B3 ${ }^{-1-}$ mice (d). Differentiation analysis of $\mathrm{BrdU}^{+}$cells performed at the time points given referred to induction of stroke (e). Stainings were performed against GFAP $(\mathbf{f}-\mathbf{g})$,

significantly higher number of $\mathrm{Ki}-67^{+}$cells within the ischemic hemisphere of ephrin-B3 ${ }^{-/-}$mice, albeit cell numbers from both mouse strains gradually declined over time (Fig. 2a). In line with this, high numbers of $\mathrm{BrdU}^{+}$ cells were found in the SVZ and the ischemic striatum from both experimental groups, with the vast majority of cells located in the striatum (Fig. 2b-d). Although the number of $\mathrm{BrdU}^{+}$cells gradually declined over time in both groups, cell numbers were always higher in ephrin-B $3^{-1-}$ mice. No $\mathrm{BrdU}^{+}$cells were found in the contralateral striatum (data not shown). On the contrary, $\mathrm{BrdU}^{+}$cells were significantly higher within the contralateral SVZ in ephrin-B3 ${ }^{-/-}$ mice at any time point analyzed. We observed, for instance, $7.5 \pm 2.4 \mathrm{BrdU}^{+}$cells $/ \mathrm{mm}^{2}$ in ephrin-B3 ${ }^{+/+}$and
$\operatorname{Dcx}(\mathbf{h}, \mathbf{i})$ and $\operatorname{NeuN}(\mathbf{j})$. Quantitative analyses were performed in both the subventricular zone (SVZ) and the ischemic striatum followed by calculation of total cell numbers. Data are given as percentages of co-localizations of $\mathrm{BrdU}$ and the specific marker referred to total numbers of $\mathrm{BrdU}^{+}$cells. Arrows indicate colocalization. Scale bar $40 \mu \mathrm{m}$. *Significantly different from ephrin$\mathrm{B} 3^{+/+}$mice, $p<0.05$

$17.0 \pm 3.5 \mathrm{BrdU}^{+}$cells $/ \mathrm{mm}^{2}$ in ephrin-B3 ${ }^{-1-}$ mice on day 28.

Differentiation analysis of proliferating cells was determined using immunohistochemical labeling of neuronal, astroglial and oligodendroglial proteins (Fig. 2e-j). Since BrdU staining at subacute time points essentially reflects activated microglia [11], initial $\mathrm{IB}_{4}$ staining was performed on day 4 post-stroke, revealing $96.4 \pm 1.4 \%$ in ephrin-B3 $^{-1-}$ versus $96.7 \pm 3.9 \%$ of co-localizations in ephrin-B3 $3^{+/+}$mice in the ischemic striatum. No co-localization of $\mathrm{BrdU}^{+}$cells with the oligodendroglial marker CNPase was found at any time point analyzed (data not shown). On the contrary, GFAP expression, which was very low on day 4 (data not shown), gradually increased 
Fig. 3 Post-ischemic neurogenesis is increased in ephrin-B3 ${ }^{-1-}$ mice. Absolute amounts of $\operatorname{Dcx}^{+}(\mathbf{a}-\mathbf{e})$ and $\mathrm{NeuN}^{+} / \mathrm{BrdU}^{+}$(f) cells were determined in ephrin-B $3^{+/+}$and ephrin-B3 ${ }^{-1-}$ mice. In ephrin$\mathrm{B}^{-1-}$ mice, $\mathrm{Dcx}^{+}$cells were significantly increased (a) in both the subventricular zone $(\mathrm{SVZ}, \mathbf{c})$ of the lateral ventricle (LV) and in the ischemic striatum (e). On the contrary, $\mathrm{Dcx}^{+}$cells in ephrin-B3 ${ }^{+/+}$ mice were reduced in both the SVZ (b) and the striatum (d). Images (b-e) represent data from day 28 post-stroke, whereas arrows indicate the location of the SVZ. Likewise, the number of $\mathrm{NeuN}^{+} / \mathrm{BrdU}^{+}$ cells was significantly increased in the ischemic striatum of ephrin-B3 ${ }^{-1-}$ mice 4 weeks after stroke (f). Scale bar $40 \mu \mathrm{m}$. *Significantly different from ephrin-B $3^{+/+}$mice; $p<0.05$
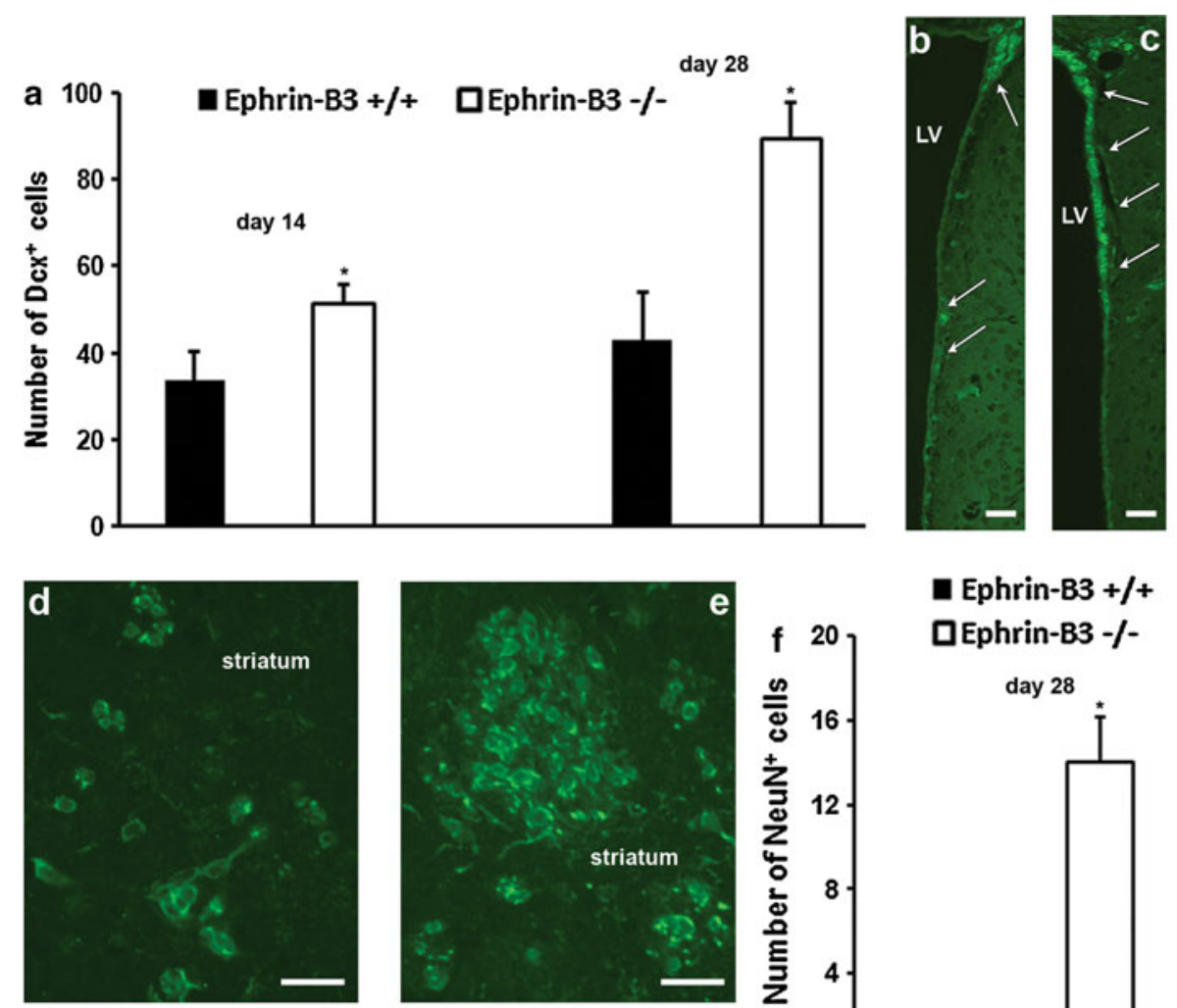

- Ephrin-B3 +/+ 口Ephrin-B3 -/-

day 28

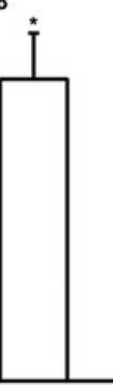

over time in both experimental groups, showing a significantly higher number of $\mathrm{BrdU}^{+} / \mathrm{GFAP}^{+}$cells from 2 weeks on in ephrin-B3 ${ }^{-/-}$mice. Distribution analysis of $\mathrm{BrdU}^{+} / \mathrm{GFAP}^{+}$cells in ephrin-B3 ${ }^{+/+}$mice revealed $39.6 \pm 5.9 \%$ of cells located in the SVZ on day 14 and $22.1 \pm 4.7 \%$ of cells residing in the SVZ on day 28 . In ephrin-B $^{-/-}$mice, $36.1 \pm 3.8 \%$ of $\mathrm{BrdU}^{+} / \mathrm{GFAP}^{+}$cells were located in the SVZ on day 14 , whereas on day 28 only $16.3 \pm 5.2 \%$ of cells were found in the SVZ. Immature neuronal differentiation, as assessed by Dcx staining on day 4, was restricted to the SVZ and enhanced in ephrin$\mathrm{B}^{-1-}$ mice, although the total amount of $\mathrm{Dcx}^{+} / \mathrm{BrdU}^{+}$ cells was very low (not shown). Over time, the number of $\mathrm{Dcx}^{+} / \mathrm{BrdU}^{+}$cells, which were from day 14 on also present in the ischemic striatum, gradually increased in both animal strains, but were always significantly higher in ephrin$\mathrm{B}^{-1-}$ mice. Distribution analysis of $\mathrm{BrdU}^{+} / \mathrm{Dcx}^{+}$cells in ephrin-B3 ${ }^{+/+}$mice revealed $38.3 \pm 7.3 \%$ of cells to be found in the SVZ on day 14 and $29.7 \pm 3.1 \%$ cells in the SVZ on day 28 . In ephrin-B3 ${ }^{-1-}$ mice, $41.7 \pm 7.3 \%$ of $\mathrm{Dcx}^{+} / \mathrm{BrdU}^{+}$cells on day 14 and $30.6 \pm 3.8 \%$ of cells on day 28 were found in the SVZ. Co-localization of BrdU ${ }^{+}$ cells with the mature neuronal marker NeuN was only observed on day 28 in ephrin-B3 ${ }^{-/-}$mice, where a few newborn cells were seen in the ischemic striatum.
Post-ischemic neurogenesis is enhanced in ephrin-B $3^{-/-}$mice

Since post-ischemic cell proliferation differed between ephrin-B3 $^{+/+}$and ephrin-B3 ${ }^{-/-}$mice (Fig. 2a, b), a postanalysis of absolute numbers of $\mathrm{Dcx}^{+}$and $\mathrm{NeuN}^{+} / \mathrm{BrdU}^{+}$ cells was performed, revealing significantly increased absolute numbers of $\mathrm{Dcx}^{+}$cells in ephrin- $3^{-1-}$ mice compared to ephrin-B $3^{+/+}$mice (Fig. 3a). Beyond day 4 post-stroke, $\mathrm{Dcx}^{+}$cells were not only restricted to the SVZ (Fig. 3b, c), but also formed typical chain-like clusters within the ischemic striatum (Fig. 3d, e). In ephrin-B3 ${ }^{+/+}$ mice, $35.6 \pm 5.4 \%$ of $\mathrm{Dcx}^{+}$cells resided in the SVZ on day 14 and $36.4 \pm 6.3 \%$ of $\mathrm{Dcx}^{+}$cells were found in the SVZ on day 28 . In ephrin-B3 ${ }^{-1-}$ mice, $37.1 \pm 7.2 \%$ of $\mathrm{Dcx}^{+}$cells were found in the SVZ on day 14 and $29.2 \pm 4.8 \%$ of $\mathrm{Dcx}^{+}$cells were observed in the SVZ on day 28 . Moreover, $\mathrm{Dcx}^{+}$cells were significantly increased in the contralateral SVZ of ephrin-B3 ${ }^{-1-}$ mice at any time point analyzed, whereas no $\mathrm{Dcx}^{+}$cells were found in the contralateral striatum of either animal strain (data not shown). Analysis of absolute numbers of $\mathrm{NeuN}^{+} / \mathrm{BrdU}^{+}$ cells at 4 weeks revealed a few scattered cells within the lesion site of ephrin-B3 ${ }^{-1-}$ mice but not within the SVZ (Fig. 3f), whereas no $\mathrm{NeuN}^{+} / \mathrm{BrdU}^{+}$cells were detectable 
in ephrin-B3 ${ }^{+/+}$mice. These data suggest that endogenous neurogenesis is increased in ephrin-B $3^{-1-}$ mice after induction of cerebral ischemia.

Post-ischemic brain injury is enhanced in ephrin-B3 ${ }^{-/-}$mice

In order to verify whether or not increased neuronal regeneration in ephrin-B3 ${ }^{-1-}$ mice was associated with higher resistance to cerebral ischemia, brain injury was analyzed for up to 4 weeks. Surprisingly, ephrin-B3 ${ }^{-1-}$ mice revealed significantly enhanced infarct volumes at any time point analyzed (Fig. 4a-g), which was associated with prominent ipsilateral edema formation (Fig. 4h), an increased number of TUNEL $^{+}$cells (Fig. 4i-k) and reduced neuronal density in these animals (Fig. 4l-n). Increased post-stroke injury, however, was not due to changes in LDF levels or impaired reperfusion between ephrin-B3 $^{-1-}$ and ephrin-B3 ${ }^{+/+}$mice (data not shown). Even more importantly, there was no significant difference in macroscopic cerebral vessel anatomy as analyzed by visualization of anastomotic lines between the ACA and the MCA territories (Fig. 4o-q) as well as by qualitative analysis of the circle of Willis (Fig. 4r, s). Enhanced brain injury in ephrin-B3 $3^{-1-}$ mice also resulted in reduced functional recovery with regard to motor coordination as assessed by the rota rod and the tightrope test (Fig. 4t, u). Noteworthily, despite the well-known loss of unilateral movement control in ephrin-B3 ${ }^{-1-}$ mice due to re-crossing projections of corticospinal tracts with subsequent simultaneous movement of both hind legs [25], pre-ischemic test performance did not differ between knockout and wildtype mice (Fig. 4t, u).

Elevation of neurogenesis in ephrin-B3 ${ }^{-1-}$ mice does not exclusively correlate with the extent of brain injury

Since cerebral ischemia itself triggers neurogenesis, we analyzed whether or not elevated neurogenesis in ephrin$\mathrm{B}^{-1-}$ mice was due to enhanced ischemic injury in these animals. Therefore, animals were exposed to either $20 \mathrm{~min}$ (ephrin-B3 ${ }^{-/-}$) or $30 \mathrm{~min}$ of ischemia (ephrin-B3 ${ }^{+/+}$), yielding no significant difference in neuronal density between the two groups (Fig. 5a). On the other hand, analysis of post-ischemic neurogenesis still yielded significantly increased numbers of both $\mathrm{Dcx}^{+}$and $\mathrm{NeuN}^{+} /$ $\mathrm{BrdU}^{+}$cells within the peri-infarct area of ephrin-B3 ${ }^{-/-}$ mice (Fig. 5b, c), which were in the same order as in animals exposed to $30 \mathrm{~min}$ of ischemia (Fig. 3a, f).

In order to further support our hypothesis that ephrin-B3 deficiency is crucial for the aforementioned observations made in ephrin-B $3^{-1-}$ mice, knockout animals received continuous intraventricular infusion of soluble ephrin-B3-
Fc via mini pumps for as long as 4 weeks. As expected, effects on both brain injury and neurogenesis were reversed by ephrin-B3-Fc-molecules, i.e., animals receiving ephrin-B3-Fc showed less prominent brain injury and reduced post-ischemic neurogenesis than control mice (Fig. 5d-f).

Aggravated ischemic injury in ephrin- $\mathrm{B} 3^{-1-}$ mice is associated with caspase-3-dependent phosphorylation of STAT1

Since the absence of ephrin-B3 has been shown to induce a caspase-3-mediated cell death under non-ischemic conditions [16], we next analyzed whether or not caspase-3 plays a role in the aggravation of brain injury in ephrin$\mathrm{B} 3^{-1-}$ mice. Caspase- 3 activity showed a maximum at $2 \mathrm{~h}$ post-stroke in both experimental groups, but was significantly higher in ephrinB3 $3^{-/}$mice at this time point and beyond (Fig. 6a). Systemic administration of the caspase-3 inhibitor z-DEVD.fmk resulted in almost completely inhibited enzyme activity in both animal strains (Fig. 6a), but yielded pronounced reduction of brain injury only in ephrin-B3 ${ }^{-1-}$ and not in ephrin-B3 ${ }^{+/+}$mice (Fig. 6b). With consideration of Eph/ephrin signaling having been shown to involve activation of STAT proteins [26], which are thought to have numerous and in part opposing effects in the pathogenesis of stroke [34, 35, 46], protein abundance of phosphorylated STAT1 and STAT3 was analyzed after induction of stroke (Fig. 6c, d). Phosphorylation levels of STAT3 did not differ between the two animal groups at $24 \mathrm{~h}$ post-stroke, and treatment with z-DEVD.fmk did not affect protein abundance. On the contrary, protein abundance of phosphorylated STAT1 was significantly increased in ephrin-B3 ${ }^{-1-}$ mice as compared to controls. Furthermore, systemic application of the caspase-3 inhibitor yielded significant reduction of STAT1 phosphorylation in ephrin-B3 ${ }^{-/-}$mice, but did not affect STAT1 phosphorylation in wild-type animals. These data suggest that aggravated ischemic brain injury in ephrin-B3 ${ }^{-1-}$ mice is associated with a caspase-3-dependent phosphorylation of STAT1.

\section{Discussion}

In the present study, we analyzed post-ischemic neurogenesis and cell proliferation, brain injury and functional neurological outcome in ephrin-B3 ${ }^{+/+}$and ephrin-B3 ${ }^{-/-}$ mice. Our study shows that post-stroke neurogenesis is enhanced in ephrin-B3 ${ }^{-1-}$ mice without contributing to functional neurological recovery. Rather, brain injury in these animals is significantly enhanced, involving a caspase-3 associated phosphorylation of STAT1. 

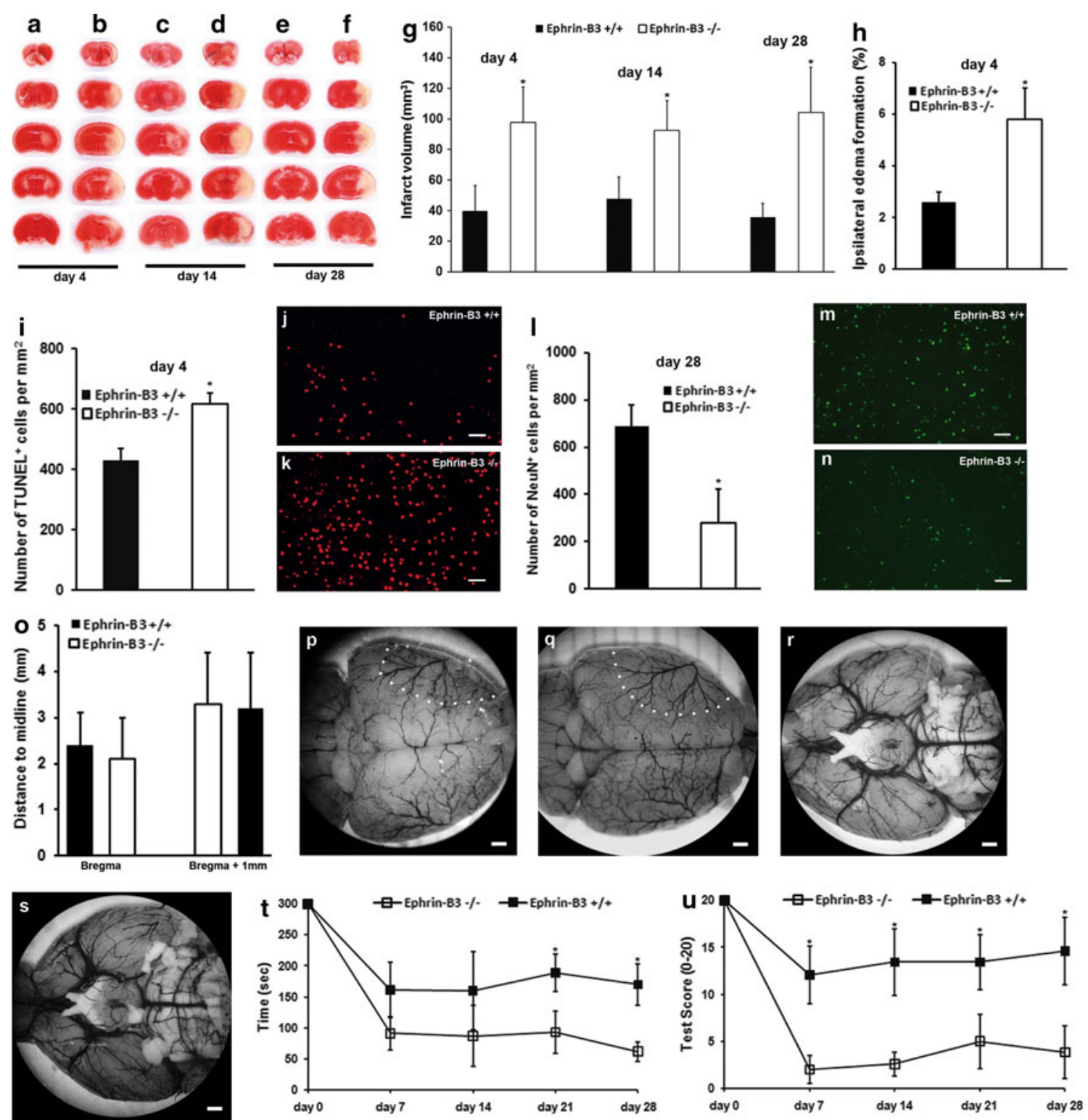

Fig. 4 Ischemic brain injury is aggravated in ephrin-B3 ${ }^{-1-}$ mice. Infarct volume analysis was performed using TTC staining (a-g) with typical examples of infarct volumes at the time points given for ephrin-B3 $^{+/+}(\mathbf{a}, \mathbf{c}, \mathbf{e})$ and ephrin-B3 ${ }^{-/-}$mice $(\mathbf{b}, \mathbf{d}, \mathbf{f})$. Ipsilateral edema formation (h) is given as relative increase of ipsilateral hemisphere volume as compared to the contralateral non-ischemic hemisphere. Immunohistochemical analysis of brain injury was assessed using TUNEL staining (i-k) and NeuN staining ("neuronal density", l-n). Macroscopic analysis of vessel anatomy (o-s) in nonischemic ephrin-B3 $3^{-/-}(\mathbf{p}, \mathbf{r})$ and ephrin-B3 ${ }^{+/+}(\mathbf{q}, \mathbf{s})$ mice after intrathoracic injection of carbon black solution. The distance from the

Eph/ephrin molecules are widely expressed throughout the SVZ, and both the surrounding tissue and Eph/ephrin interactions in these regions have been shown to affect proliferation and apoptosis $[8,20,24,32]$. The role of ephrin-B3 in adult neurogenesis and neurosphere formation has been described under physiological conditions [32]. midline of the anastomotic line between the anterior cerebral artery (ACA) and the middle cerebral artery (MCA) vascular territory was determined at the level of bregma and at $+1 \mathrm{~mm}$ from bregma $(\mathbf{o}-\mathbf{q})$. Anastomotic lines between the left ACA and MCA territories were determined by tracing peripheral branches on dorsal brain surfaces to the points at which vessels were connected (p-q; indicated by dotted lines). Post-stroke motor coordination deficits were assessed in ephrin-B3 ${ }^{-/-}$and ephrin-B3 ${ }^{+/+}$mice using the rota rod (t) and the tightrope test (u) at the time points given. Scale bar $1 \mathrm{~mm}$. $*$ Significantly different from ephrin-B $3^{+/+}$mice, $p<0.05$

However, as neurosphere formation and neurogenesis depend on the species and the age of the animal [4, 5, 40], these results cannot be transferred to our experimental paradigm, which included older animals. In line with Ricard et al. [32] showing an increased self-renewal capacity of NPCs isolated from ephrin-B $3^{-1-}$ mice, we found enhanced 

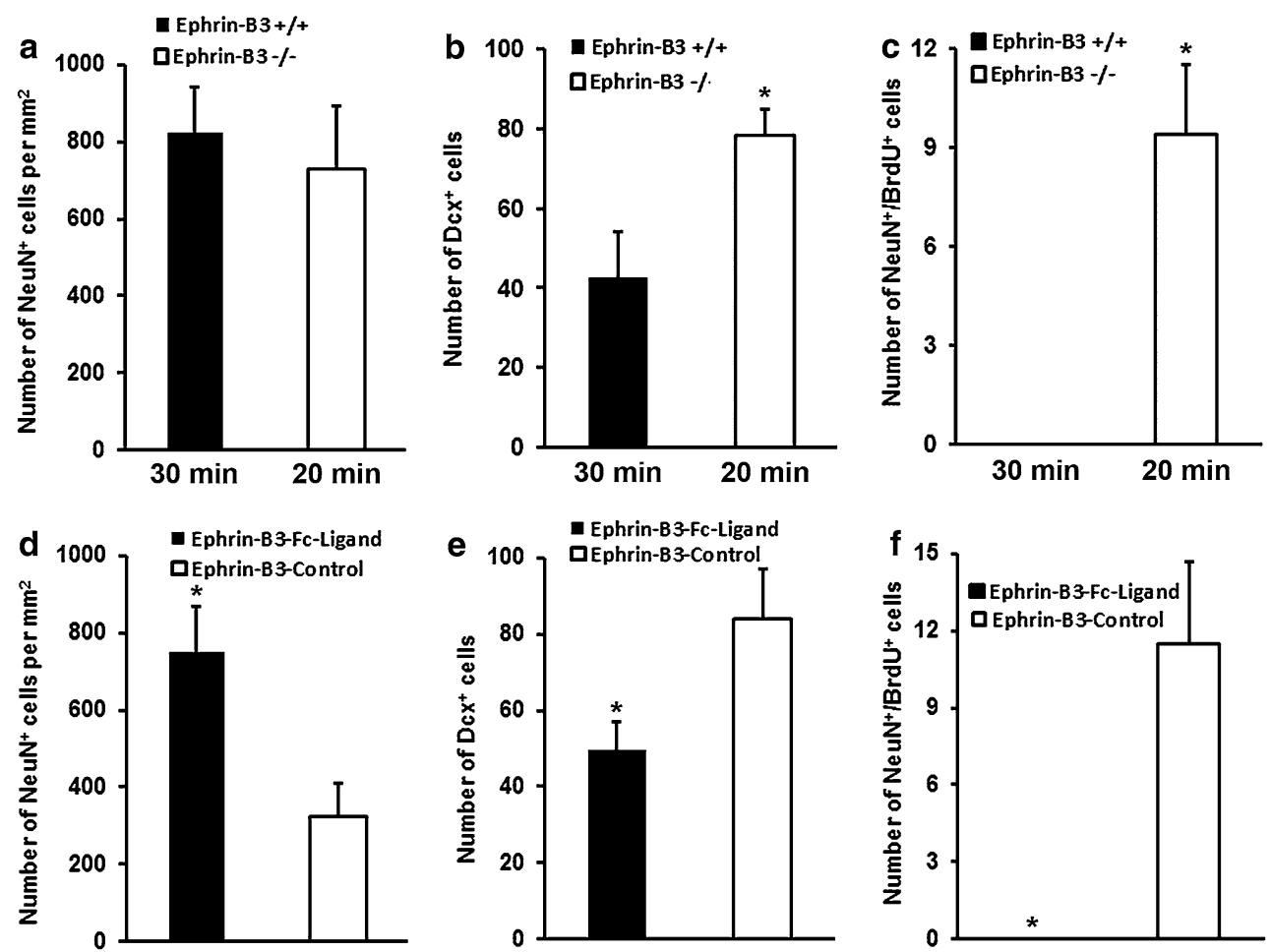

Fig. 5 Enhanced post-ischemic neurogenesis in ephrin-B3 ${ }^{-1-}$ mice does not exclusively correlate to the extent of brain injury. All data af refer to day 28 post-stroke. a-c Animals were exposed to $20 \mathrm{~min}$ $\left(\right.$ ephrin-B3 ${ }^{-l-}$ ) or $30 \mathrm{~min}$ (ephrin-B3 ${ }^{+/+}$) of cerebral ischemia followed by NeuN staining for assessment of "neuronal density" (a). Post-ischemic neurogenesis was assessed analyzing total absolute amounts of $\mathrm{Dcx}^{+}$(b) and $\mathrm{NeuN}^{+} / \mathrm{BrdU}^{+}$(c) cells in both animal strains. d-f Analysis of "neuronal density" (d) and numbers of Dcx ${ }^{+}$ (e) as well as $\mathrm{NeuN}^{+} / \mathrm{BrdU}^{+}$(f) cells in ephrin-B3 ${ }^{-1-}$ mice that received intraventricular infusion for 28 days of either ephrin-B3-Fc or Fc-fragments as control. *Significantly different from ephrin-B3 ${ }^{+/+}$ or ephrin-B $3^{-1-}$ control mice, $p<0.05$ neurosphere formation and cell proliferation rates of NPCs derived from ephrin-B $3^{-1-}$ mice, which was associated with significantly increased astroglial and neuronal differentiation rates. Noteworthily, cell differentiation rates were independent of cell passage states, i.e., there was no difference between primary NPCs and NPCs from passage 3 .

Although the SVZ itself is not affected by focal cerebral ischemia [12], we further analyzed whether or not NPCs from both mouse strains show different resistance rates against OGD. Importantly, no significant difference was observed, which might be due to the fact that ephrin-B3 is not expressed in the SVZ itself but in the surrounding tissue, which seems to only indirectly affect proliferation and differentiation of NPCs [32].

Cerebral ischemia stimulates endogenous cell proliferation and neurogenesis [2, 21]. Accordingly, strokeinduced high cell proliferation rates within the lesion site of both animal strains. Cell proliferation in the ischemic hemisphere as well as in the contralateral non-ischemic SVZ, however, was always higher in ephrin-B $3^{-1-}$ than in ephrin-B ${ }^{+/+}$mice, suggesting that basal cell proliferation within the germinal niche of ephrin- $\mathrm{B} 3^{-/-}$mice is enhanced, as has been previously shown under physiological conditions [32].

A differentiation analysis of proliferating cells revealed a high $\mathrm{IB}_{4}$ abundance of these cells on day 4 , reflecting rather activation of microglia than cell differentiation of $\mathrm{BrdU}^{+}$cells. The decline of cell proliferation over time in both experimental groups therefore most likely reflects a decreased inflammatory response in the ischemic tissue, which is in line with our previous observations where subacute post-stroke cell proliferation was due to microglia activation and not due to enhanced neurogenesis [11]. Astroglial differentiation analysis of proliferating cells revealed an increase over time in both ephrin-B3 ${ }^{+/+}$and ephrin-B $3^{-1-}$ mice, but were found to be higher in the knockout group from day 14 on. Immature neuronal differentiation of $\mathrm{BrdU}^{+}$proliferating cells increased over time in both experimental groups, which is consistent with previous reports, where stroke has been shown to increase neuronal differentiation of $\mathrm{BrdU}^{+}$cells $[2,3,12,48]$. Nevertheless, immature neuronal differentiation of proliferating cells was always higher in ephrin-B $3^{-1-}$ mice. In spite of this, no newborn mature neurons in the ischemic 

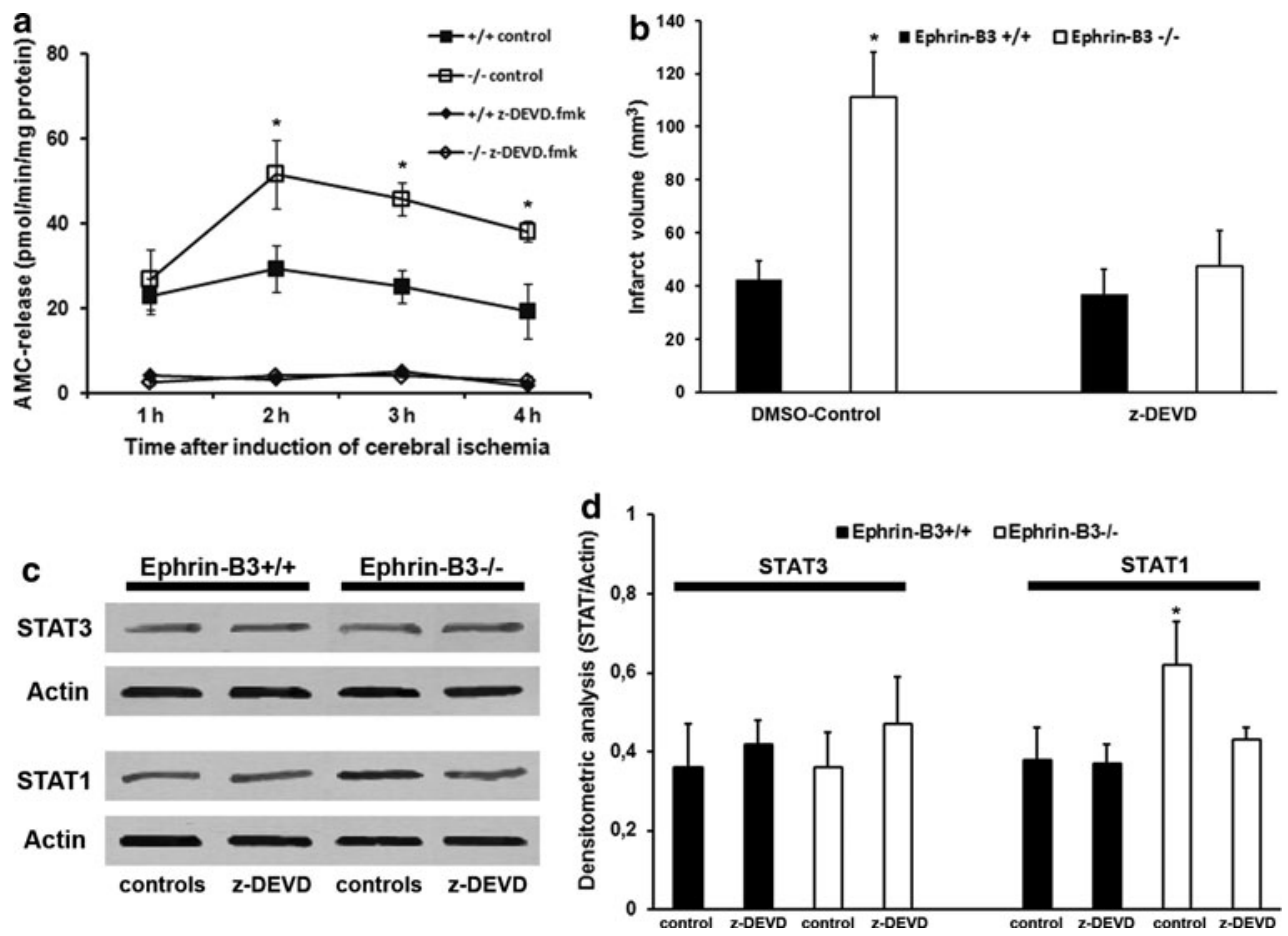

Fig. 6 Aggravated injury in ephrin-B $3^{-1-}$ mice is associated with caspase-3-dependent phosphorylation of STAT1. a Caspase-3 activity was determined between 1-4 h after induction of stroke in ephrin$\mathrm{B}^{+/+}$(black symbols) and ephrin-B3 ${ }^{-1-}$ (open symbols) mice that were given i.v. injections of either $0.2 \%$ DMSO as control or the caspase-3 inhibitor z-DEVD.fmk at the beginning of the reperfusion.

hemisphere in ephrin-B3 ${ }^{+/+}$mice were observed, whereas only a few scattered $\mathrm{NeuN}^{+} / \mathrm{BrdU}^{+}$cells were found in ephrin-B3 ${ }^{-1-}$ mice 4 weeks post-stroke. In line with this, absolute amounts of newborn neuronal cells, which are more relevant for neuroregeneration, were also significantly increased in ephrin-B3 ${ }^{-1-}$ mice. The low neuronal differentiation rates observed in ephrin-B $3^{-1-}$ mice might, however, also be in part due to the limited observation period of 4 weeks with a maximum age of newborn cells of 20 days due to the BrdU-labeling protocol. Although increased neuronal differentiation of $\mathrm{BrdU}^{+}$cells in ephrin$\mathrm{B}^{-1-}$ mice has been described before under physiological conditions [32], this is the first time where increased neuronal differentiation in these animals was observed under ischemic conditions. Similarly, enhanced proliferation of SVZ-derived NPCs has recently been described after induction of traumatic brain injury (TBI) in ephrin-B3 ${ }^{-/-}$ mice via a p53-dependent pathway [38]. Since stroke and TBI share pathophysiological aspects, including inflammation, further studies have to address the question whether or not p53 is also involved in enhanced proliferation of SVZ-derived NPCs after cerebral ischemia in ephrin-B3 ${ }^{-1-}$ mice.

As post-stroke neurogenesis was significantly increased in ephrin-B $3^{-1-}$ mice, we further analyzed whether or not b TTC staining on day 4 post-stroke in animals that had received systemic application of either z-DEVD.fmk or DMSO on days 0-3. c Detection of phosphorylated STAT1 and STAT3 in ipsilateral hemispheres at $24 \mathrm{~h}$ after stroke using Western blotting with subsequent densitometric analysis (d) referred to actin abundance. *Significantly different from ephrin-B $3^{+/+}$mice, $p<0.05$

this phenomenon was associated with enhanced resistance to stroke and improved post-stroke recovery. Surprisingly, knockout animals suffered from extensive ischemic brain injury, which was neither due to impaired blood flow nor to differences in vessel anatomy, ultimately resulting in impaired functional recovery of ephrin-B3 ${ }^{-l-}$ mice. In this context, the aforementioned enhanced numbers of $\mathrm{GFAP}^{+} /$ $\mathrm{BrdU}^{+}$cells in ephrin-B3 ${ }^{-1-}$ animals might rather reflect astroglial proliferation during scar formation than genuine astroglial differentiation of SVZ-derived $\mathrm{BrdU}^{+}$cells.

As stroke triggers neurogenesis [39], we analyzed whether the enhanced neurogenesis observed in ephrin$\mathrm{B}^{-1-}$ mice might be due to mere increased brain injury in these animals. Reduction of thread occlusion time in knockout animals resulting in similar infarct sizes compared to wild-type animals did not, however, affect neurogenesis in ephrin-B3 ${ }^{-1-}$ mice. Not only was postischemic neurogenesis increased when compared to wildtype animals, but was also as high as in ephrin-B $3^{-1-}$ mice that were exposed to longer times of MCA occlusion. In this context, proof of principle experiments using continuous intraventricular infusion of soluble ephrin-B3Fc-molecules in ephrin-B3 ${ }^{-1-}$ mice reversed the aforementioned observations, i.e., both brain injury and neurogenesis were decreased in these animals. As such, 
enhanced post-ischemic endogenous neurogenesis in ephrin-B $3^{-1-}$ mice does not exclusively depend on the extent of ischemic injury, but is also in part a consequence of intrinsic properties within the knockout mouse.

Although the role of apoptosis and activation of caspase3 in cerebral ischemia have been studied before, precise apoptotic pathways and demonstration of clinical benefits are still elusive [6, 10, 28]. Interestingly, activation of caspase- 3 recently has been shown to occur in the absence of ephrin-B3, resulting in apoptotic cell death under nonischemic conditions [16]. In the present study, determination of post-stroke caspase-3 activity revealed a significant increase in ephrin-B3 ${ }^{-1-}$ mice when compared to controls. Although systemic application of the caspase-3 inhibitor z-DEVD.fmk significantly reduced caspase-3 activity in both animal strains, infarct volumes were only decreased in ephrin-B $^{-/-}$but not in ephrin-B3 ${ }^{+/+}$mice. Noteworthily, ephrin-B $^{+/+}$and ephrin-B3 ${ }^{-/-}$mice developed similar infarct volumes after treatment with the caspase-3 inhibitor. Therefore, caspase- 3 activation might be one critical pathway involved in the aggravation of stroke injury in ephrin-B3 $^{-1-}$ mice.

As STAT proteins are mediators of Eph/ephrin signaling [26], the abundance of phosphorylated STAT1 and STAT3 was analyzed, resulting in enhanced STAT1 abundance in ephrin-B $^{-1-}$ mice $24 \mathrm{~h}$ post-stroke. On the contrary, no difference in phosphorylated STAT3 abundance between knockout and wild-type animals was observed. Interestingly, systemic application of the caspase-3 inhibitor yielded significantly reduced abundance of phosphorylated STAT1 in ephrin-B3 ${ }^{-1-}$ mice, suggesting that a caspase-3dependent activation of STAT1 might be involved in the aggravation of brain injury in ephrin-B3 ${ }^{-1-}$ mice. Nevertheless, the role of STAT proteins in cerebral ischemia and other pathological conditions is still elusive and in part contradictory. STAT proteins are important intracellular mediators of cytokines, among which STAT3 is generally thought rather to induce neuroprotection than cell death $[22,30]$. On the contrary, activation of STAT1 has been described to induce both cell injury and neuroprotection under different pathological conditions [18]. We here describe a caspase-3-dependent phosphorylation of STAT1 under ischemic conditions for the first time. In order to verify whether or not aggravation of ischemic injury in ephrin-B $^{-1-}$ mice is solely dependent on caspase-3mediated activation of STAT1, further studies are required. However, this beyond the scope of the present work.

In conclusion, our study demonstrates that post-ischemic endogenous neurogenesis is increased in ephrin-B3 ${ }^{-1-}$ mice. Ephrin-B3 deficiency, however, also leads to increased brain injury and subsequent impaired neurological recovery, which is associated with a post-ischemic caspase-3-mediated activation of STAT1, pointing towards the notion that cell proliferation, neurogenesis and neurological recovery do not necessarily go in line with each other after stroke. Nevertheless, enhanced proliferation and neuronal differentiation rates of ephrin-B $3^{-1-}$ derived NPCs might be one interesting tool for overcoming the limitations of cell-based therapies in cerebral ischemia, such as poor survival and low differentiation rates of transplanted cells.

Acknowledgments We thank Britta Kaltwasser for excellent technical assistance. This work was supported by the DFG Research Center for the Molecular Physiology of the Brain (M.B.), the Internal Research Program of the University of Goettingen (T.R.D.) and the Cluster of Excellence "Macromolecular Complexes" DFG-EXC115 (A.A-P.).

Conflict of interest The authors declare that they have no conflicts of interest.

\section{References}

1. Alvarez-Buylla A, Garcia-Verdugo JM (2002) Neurogenesis in adult subventricular zone. J Neurosci 22:629-634

2. Arvidsson A, Collin T, Kirik D, Kokaia Z, Lindvall O (2002) Neuronal replacement from endogenous precursors in the adult brain after stroke. Nat Med 8:963-970

3. Arvidsson A, Kokaia Z, Lindvall O (2001) N-methyl-D-aspartate receptor-mediated increase of neurogenesis in adult rat dentate gyrus following stroke. Eur J Neurosci 14:10-18

4. Baker SA, Baker KA, Hagg T (2005) D3 dopamine receptors do not regulate neurogenesis in the subventricular zone of adult mice. Neurobiol Dis 18:523-527

5. Bouab M, Paliouras GN, Aumont A, Forest-Berard K, Fernandes KJ (2011) Aging of the subventricular zone neural stem cell niche: evidence for quiescence-associated changes between early and mid-adulthood. Neuroscience 173:135-149

6. Broughton BR, Reutens DC, Sobey CG (2009) Apoptotic mechanisms after cerebral ischemia. Stroke 40:e331-e339

7. Chojnacki A, Weiss S (2008) Production of neurons, astrocytes and oligodendrocytes from mammalian CNS stem cells. Nat Protoc 3:935-940

8. Conover JC, Doetsch F, Garcia-Verdugo JM et al (2000) Disruption of Eph/ephrin signaling affects migration and proliferation in the adult subventricular zone. Nat Neurosci 3:1091-1097

9. Dayer AG, Ford AA, Cleaver KM, Yassaee M, Cameron HA (2003) Short-term and long-term survival of new neurons in the rat dentate gyrus. J Comp Neurol 460:563-572

10. Dirnagl U, Iadecola C, Moskowitz MA (1999) Pathobiology of ischaemic stroke: an integrated view. Trends Neurosci 22: 391-397

11. Doeppner TR, Dietz GP, Weise J, Bahr M (2010) Protection of hippocampal neurogenesis by TAT-Bcl-x(L) after cerebral ischemia in mice. Exp Neurol 223:548-556

12. Doeppner TR, Nagel F, Dietz GP, Weise J, Tonges L, Bähr M (2009) TAT-Hsp70-mediated neuroprotection and increased survival of neuronal precursor cells after focal cerebral ischemia in mice. J Cereb Blood Flow Metab 29:1187-1196

13. Doetsch F, Caille I, Lim DA, Garcia-Verdugo JM, AlvarezBuylla A (1999) Subventricular zone astrocytes are neural stem cells in the adult mammalian brain. Cell 97:703-716 
14. Doetsch F, Garcia-Verdugo JM, Alvarez-Buylla A (1997) Cellular composition and three-dimensional organization of the subventricular germinal zone in the adult mammalian brain. J Neurosci 17:5046-5061

15. Flanagan JG, Vanderhaeghen P (1998) The ephrins and Eph receptors in neural development. Annu Rev Neurosci 21:309-345

16. Furne C, Ricard J, Cabrera JR et al (2009) EphrinB3 is an antiapoptotic ligand that inhibits the dependence receptor functions of EphA4 receptors during adult neurogenesis. Biochim Biophys Acta 1793:231-238

17. Gerlai R, Thibodeaux H, Palmer JT, van Lookeren Campagne M, Van Bruggen N (2000) Transient focal cerebral ischemia induces sensorimotor deficits in mice. Behav Brain Res 108:63-71

18. Gorina R, Sanfeliu C, Galito A, Messeguer A, Planas AM (2007) Exposure of glia to pro-oxidant agents revealed selective Stat1 activation by $\mathrm{H} 2 \mathrm{O} 2$ and Jak2-independent antioxidant features of the Jak2 inhibitor AG490. Glia 55:1313-1324

19. Gross CG (2000) Neurogenesis in the adult brain: death of a dogma. Nat Rev Neurosci 1:67-73

20. Holmberg J, Armulik A, Senti KA et al (2005) Ephrin-A2 reverse signaling negatively regulates neural progenitor proliferation and neurogenesis. Genes Dev 19:462-471

21. Jin K, Minami M, Lan JQ et al (2001) Neurogenesis in dentate subgranular zone and rostral subventricular zone after focal cerebral ischemia in the rat. Proc Natl Acad Sci USA 98:4710-4715

22. Jung JE, Kim GS, Chen H et al (2010) Reperfusion and neurovascular dysfunction in stroke: from basic mechanisms to potential strategies for neuroprotection. Mol Neurobiol $41: 172-179$

23. Kaneko N, Sawamoto K (2009) Adult neurogenesis and its alteration under pathological conditions. Neurosci Res 63:155-164

24. Katakowski M, Zhang Z, de Carvalho AC, Chopp M (2005) EphB2 induces proliferation and promotes a neuronal fate in adult subventricular neural precursor cells. Neurosci Lett 385:204-209

25. Kullander K, Croll SD, Zimmer M, Pan L, McClain J (2001) Ephrin-B3 is the midline barrier that prevents corticospinal tract axons from recrossing, allowing for unilateral motor control. Genes Dev 15:877-888

26. Lai K-O, Chen Y, Po H-M et al (2004) Identification of the Jak/ stat proteins as novel downstream targets of epha4 signaling in muscle. J Biol Chem 279:13383-13392

27. Liu J, Solway K, Messing RO, Sharp FR (1998) Increased neurogenesis in the dentate gyrus after transient global ischemia in gerbils. J Neurosci 18:7768-7778

28. Namura S, Zhu J, Fink K et al (1998) Activation and cleavage of caspase-3 in apoptosis induced by experimental cerebral ischemia. J Neurosci 18:3659-3668

29. Palmer A, Klein R (2003) Multiple roles of ephrins in morphogenesis, neuronal networking, and brain function. Genes Dev 17:1429-1450

30. Planas AM, Gorina R, Chamorro A (2006) Signalling pathways mediating inflammatory responses in brain ischaemia. Biochem Soc Trans 34(Pt 6):1267-1270

31. Reitmeir R, Kilic E, Kilic U et al (2011) Post-acute delivery of erythropoietin induces stroke recovery by promoting perilesional tissue remodelling and contralesional pyramidal tract plasticity. Brain 134(Pt 1):84-99

32. Ricard J, Salinas J, Garcia L, Liebl DJ (2006) EphrinB3 regulates cell proliferation and survival in adult neurogenesis. Mol Cell Neurosci 31:713-722

33. Rietze RL, Reynolds BA (2006) Neural stem cell isolation and characterization. Methods Enzymol 419:3-23

34. Shyu W-C, Lin S-Z, Chiang M-F et al (2008) Secretoneurin promotes neuroprotection and neuronal plasticity via the Jak2/ Stat3 pathway in murine models of stroke. J Clin Invest 118:133-148

35. Takagi Y, Harada J, Chiarugi A, Moskowitz MA (2002) STAT1 is activated in neurons after ischemia and contributes to ischemic brain injury. J Cereb Blood Flow Metab 22:1311-1318

36. Taupin $P$ (2006) Neurogenesis in the adult central nervous system. C R Biol 329:465-475

37. Taupin P, Gage FH (2002) Adult neurogenesis and neural stem cells of the central nervous system in mammals. J Neurosci Res 69:745-749

38. Theus MH, Ricard J, Bethea JR, Liebl DJ (2010) EphB3 inhibits the expansion of neural progenitor cells in the svz by regulating p53 during homeostasis and following traumatic brain injury. Stem Cells 28(7):1231-1242

39. Thored P, Arvidsson A, Cacci E et al (2006) Persistent production of neurons from adult brain stem cells during recovery after stroke. Stem Cells 24:739-747

40. Van Kampen JM, Hagg T, Robertson HA (2004) Induction of neurogenesis in the adult rat subventricular zone and neostriatum following dopamine D3 receptor stimulation. Eur J Neurosci 19:2377-2387

41. Wacker BK, Park TS, Gidday JM (2009) Hypoxic preconditioning-induced cerebral ischemic tolerance: role of microvascular sphingosine kinase 2. Stroke 40:3342-3348

42. Wang Y, Kilic E, Kilic U et al (2005) VEGF overexpression induces post-ischaemic neuroprotection, but facilitates hemodynamic steal phenomena. Brain 128:52-63

43. Wilkinson DG (2001) Multiple roles of EPH receptors and ephrins in neural development. Nat Rev Neurosci 2:155-164

44. Xing S, He Y, Ling L et al (2008) Blockade of EphB2 enhances neurogenesis in the subventricular zone and improves neurological function after cerebral cortical infarction in hypertensive rats. Brain Res 1230:237-246

45. Yamashita T, Ninomiya M, Hernandez Acosta P et al (2006) Subventricular zone-derived neuroblasts migrate and differentiate into mature neurons in the post-stroke adult striatum. J Neurosci 26:6627-6636

46. Yi J-H, Park S-W, Kapadia R, Vemuganti R (2007) Role of transcription factors in mediating post-ischemic cerebral inflammation and brain damage. Neurochem Int 50:1014-1027

47. Yoo SW, Kim SS, Lee SY et al (2008) Mesenchymal stem cells promote proliferation of endogenous neural stem cells and survival of newborn cells in a rat stroke model. Exp Mol Med 40:387-397

48. Zhang RL, Zhang ZG, Zhang L, Chopp M (2001) Proliferation and differentiation of progenitor cells in the cortex and the subventricular zone in the adult rat after focal cerebral ischemia. Neuroscience 105:33-41 